\title{
Tax and Business Issues on Asset-Backed Securitization in Indonesia
}

\author{
Wulandari Kartika Sari*, Fatmah Sabrina, Milla Sepliana Setyawati \\ Department of Fiscal Administration \\ University of Indonesia \\ Depok, Indonesia \\ *ks.wulandari87@gmail.com, shabrinasymln@gmail, milla.s.setyowati@gmail
}

\begin{abstract}
Asset securitization is an alternative source of innovative infrastructure funding to achieve large infrastructure financing targets in Indonesia. This asset securitization study aims to discuss regulatory issues in business categories and tax implications related to $\mathrm{CIC}-\mathrm{ABS}$ in Indonesia. This research using a qualitative approach and descriptive research type conducted from February 2020 to July 2020. The results show that there are no regulations regarding the form of business of CIC ABS in Indonesia. Thus, CIC ABS does not get an exemption from withholding Income Tax Article 23 on margin income. It resulted in overpayments of taxes and economic double-taxation, which disrupted the liquidity of CIC ABS.
\end{abstract}

Keywords-asset-backed securitization, collective investment contract, financial instrument, income tax

\section{INTRODUCTION}

Indonesia has the potential to become one of the world's economic powers. However, steps to achieve Indonesia as the axis of world economic power still hampered by various conditions, one of which is related to the availability of adequate infrastructure both in quantity and quality. Infrastructure limitations correlate with inefficiencies in the country's economy, driven by very high logistics costs, which will affect businesses' competitiveness. Also, it will lead to social inequality.

Realizing this condition, the Indonesian government has begun to stretch back to place infrastructure development as one of the government's focuses through larger APBN budget allocation. However, the Covid-19 pandemic has forced all countries, including Indonesia, to adjust the government budget in the context of tackling the coronavirus outbreak that has started plaguing Indonesia since March 2020. Even under normal conditions, the state budget allocation for infrastructure is limited. On average, since 2014-2019 can only support $20 \%$ of the total investment in infrastructure development, with state financing, which has been mainly supported by tax revenues, with the last five years experiencing a shortfall.

The picture of the government's limited infrastructure financing should encourage the Indonesian government to look for alternative infrastructure financing in the future, especially in economic recovery conditions since the outbreak of the COVID 19 outbreak in Indonesia. The Indonesian government needs to consider government non-budget investment financing (PINA), including state-owned enterprises' involvement. However, the limited capital of BUMN is one of the problems that need to be solved. An alternative solution that is considered is the issuance of asset-backed securities (ABS). Through this investment scheme, BUMN can increase its capital by transforming illiquid assets into liquid assets. Asset securitization is an alternative source of innovative infrastructure funding to achieve large infrastructure financing targets in Indonesia [1]. At the end of August 2017, PT Jasa Marga Tbk issued a Collective Investment Contract - AssetBacked Securities (CIC ABS) Securities for Jakarta Bogor Ciawi Toll Road Revenue [2]. Continued in September 2017, PT. Indonesia Power, as a subsidiary of PT. PLN officially securitizes assets in a portion of the electricity sales receivable.

The realization of asset securitization in encouraging investment managers and banks as custodians and attracting investors must be supported by attractive regulations and incentives for all parties. Include financial regulation and taxation. ABS's issuance in Indonesia is only permitted in a Collective Investment Contract (CIC) as regulated in the capital market regulations (POJK 65/2017). It means that ABS issuance can only be done through a collective investment contract scheme as long as this regulation is still in effect. It is slightly different from the asset securitization mechanism in many countries that uses a Special Purpose Vehicle as an ABS issuer.

Besides, tax regulations are often an influencing factor in the issuance of capital market instruments. The Financial Services Authority has expressed hope of relaxing taxes on several investment instruments in the capital market to support infrastructure development to attract investors, including CIC ABS [2]. With the relaxation of taxation on capital market instruments, infrastructure assets can develop more rapidly, be more competitive, and attract foreign and domestic investors.

This asset securitization study aims to discuss regulatory issues in business categories and tax implications related to CIC-ABS in Indonesia. This CIC-ABS study will explain the 
capital market regulations and taxation for CIC ABS applied in Indonesia and their business implications. This study seeks to complement the previous study, providing new findings regarding the discussion of asset securitization in the form of asset-backed effects, particularly in the context of taxation in Indonesia. Some of the studies reviewed are "Tax Treatment of Securitisations of Receivables" by Bhattarai and Baxi [3], "Asset Securitization is as an Alternative Strategy in Financing at Bank XYZ" by Amelia [4], "Asset Securitization Financing Institutions and Market Development of Secondary Mortgage Facilities in the Context of Deepening the Indonesian Financial Market" by Suselo et al. [5], and "Corporate Tax and Securitization" by Han et al. [6]. Previous studies have not discussed legal regulations and their impact on the taxation of CIC-ABS transactions in Indonesia, which led to this research.

This paper will present findings on business and taxation issues that characterize the issuance of Asset-Backed Securities through Collective Investment Contracts in Indonesia. The results obtained to be input for the preparation of regulations regarding CIC ABS that are more investment-friendly so that their use as an alternative state financing instrument for developing the real sector and infrastructure can optimally realize.

\section{Methodology}

This research conducted using qualitative research methods and approaches and classified as a descriptive research type. The research involved a series of procedures to reveal and understand the object's meaning understudy, the Asset-Backed Securities Collective Investment Contract. The primary data collected by involving the questions asked through in-depth interviews with the intended sources and secondary sources with the study of relevant literature. The analysis was built inductively on data obtained through literature review and field research with various interviewees, namely the Directorate General of Taxes, the Fiscal Policy Agency, the Financial Services Authority, CIC-ABS Representatives, Tax Practitioners, Tax Academics, and Legal Academics. The data obtained were then analyzed using the relevant theory.

The research focuses on reviewing capital market regulations and taxes related to CIC-ABS and their implications for ABS transactions in Indonesia. The research was conducted from February 2020 to July 2020 to obtain the latest relevant data on CIC ABS regulations and transactions in Indonesia.

\section{RESULTS}

The determination of CIC as an ABS issuer in Indonesia by the Financial Services Authority (OJK) as the Indonesian capital market authority, adopted the SPV pattern. Thus, the CIC pattern has almost the same characteristics as Trust in the United States. Illustrated by the comparison of the characteristics between CIC-ABS and Trust in the following table 1:
TABLE I. COMPARISON OF TRUST AND CIC-ABS

\begin{tabular}{|l|l|l|}
\hline \multicolumn{1}{|c|}{ Characteristic } & \multicolumn{1}{|c|}{ Trust } & CIC-ABS \\
\hline $\begin{array}{l}\text { There are asset holders, managers, } \\
\text { beneficiaries }\end{array}$ & Yes & Yes \\
\hline Specific assets or properties & Yes & Yes \\
\hline Based on the wishes of the manager & Yes & Yes \\
\hline Created for lawful purposes & Yes & Yes \\
\hline $\begin{array}{l}\text { The trustee has obligations to property } \\
\text { and beneficiaries }\end{array}$ & Yes & Yes \\
\hline $\begin{array}{l}\text { Asset holders and managers receive } \\
\text { remuneration }\end{array}$ & Yes & Yes \\
\hline
\end{tabular}

CIC-ABS is a contract between an investment manager and a custodian bank that binds the asset-backed securities holder wherein the investment manager is authorized to manage collective investment portfolios, and the custodian bank is authorized to carry out collective custody [7].

Asset-Backed Securities (ABS) is securities issued by CICABS whose portfolio consists of financial assets as the underlying asset (Article 1 number 1 POJK-65/2017). ABS was carried out in funding needs, especially for originators of large infrastructure financing [8.] CIC is the form of law most often used in Indonesia. The form of CIC is chosen as the issuer of ABS because this CIC is seen as more flexible than a Limited Liability Company (PT), partly because CIC is not required to have the organs required for PT, namely the Board of Commissioners, the Board of Directors and the General Meeting of Shareholders (GMS) under Article 1 number 2 of Law Number 40 of 2007 concerning Limited Liability Companies. CIC was chosen as the ABS issuer as a form equivalent to the Special Purpose Vehicle (SPV) in Indonesia. However, it is different from the form of SPV as a particular entity established to handle asset securitization, using the concept of trust, which does not apply in Indonesia, as a country that adheres to a civil law system [9].

In terms of taxation, CIC ABS is designated as a Corporate Tax Subject in Indonesia that classifies Collective Investment Contracts as other forms of entity equated with a corporate entity [10]. The status makes CIC-ABS have the same tax obligations as the Corporate Taxpayer in general, although it is just a legal contract. CIC-ABS must fulfill the obligation to register, calculate, pay or deposit, and report taxes under the applicable laws and regulations.

Income Tax provisions on the income received or obtained by CIC ABS and its investors further regulated in the Decree of the Director-General of Taxes Number KEP-147/PJ.04/ 2003 [8]. Last year, a regulation related to CIC ABS was issued, Government Regulation Number 5 of 2019, which regulates a special rate for Final Income Tax on bond interest received by CIC ABS. Until now, no taxation scheme or concept regulates the tax treatment of CIC ABS explicitly. The current tax regulations for $\mathrm{CIC}$-ABS provide unfavorable conditions for CIC ABS liquidity, as illustrated below on table 2: 
TABLE II. ILLUSTRATION OF KIK-EBA INCOME TAX CALCULATION

\begin{tabular}{|c|c|c|}
\hline No. & Description & Amount $+/(-)$ \\
\hline \multicolumn{3}{|c|}{ Stage 1: Taxable Income Calculation } \\
\hline & Gross Income (Principal 400 + Margin 50) & 450 \\
\hline & (costs to earn, collect, and maintain income) & (2) \\
\hline & $\begin{array}{l}\text { (fees paid or payable to investment managers, } \\
\text { Custodian Banks, accountants, service } \\
\text { providers, rating agencies, legal consultants, } \\
\text { notaries, and other parties) } \\
* \text { assumption: } 2 \% \text { of the principal }\end{array}$ & (8) \\
\hline & $\begin{array}{l}\text { (refund of principal to the unitholder of KIK- } \\
\text { EBA Fixed Cash Flow) }\end{array}$ & (400) \\
\hline & $\begin{array}{l}\text { (interest compensation to KIK-EBA Fixed Cash } \\
\text { Flow unit holders) } \\
* \text { assumption: } 10 \% \text { of the principal }\end{array}$ & (40) \\
\hline & Total Taxable Income & 0 \\
\hline \multicolumn{3}{|c|}{ Stage 2: Income Tax Calculation } \\
\hline & Taxable Income & 0 \\
\hline & $\begin{array}{l}\text { Total Income Tax Payable (Taxabel Inc. x CIT } \\
\text { Rates) }\end{array}$ & 0 \\
\hline & $\begin{array}{l}\text { Domestic Tax Credit }(15 \% \times 50) \\
-- \text { Income Tax Article } 23 \text { on the margin } \\
\text { withheld by the Originator-- }\end{array}$ & $(7,5)$ \\
\hline & Underpaid Income Tax / (Overpaid) & $(7,5)$ \\
\hline
\end{tabular}

CIC ABS in Indonesia generally experience this condition of overpaying taxes. This matter needs to be reviewed further by the tax authorities. Further regulation is needed.

\section{DISCUSSION}

\section{A. Overview of CIC ABS Business Category Issues}

CIC ABS is an investment instrument in the capital market. However, no regulation explicitly states the CIC-ABS business category, whether as a financial service, a financing institution, the same as a bank, or others [11]. Based on the transactions, CIC-ABS can at least be equated with factoring because it has the same characteristics as factoring, which is one of the business activities of a financing company in Indonesia. CIC $\mathrm{ABS}$ and factoring similarity is because CIC-ABS buys underlying assets in the form of financial assets, including various types of receivables from the Originator.

Thus, if the underlying asset is a form of receivables or the like, the CIC-ABS should also be treated as a financing institution. However, CIC-ABS cannot qualify as a Financing Company. PMK-84/2006 stipulates that a finance company established in a Limited Liability Company (PT) or a Cooperative. To be recognized as a finance company, one must obtain a business license as a finance company from the Minister of Finance. In reality, CIC-ABS does not meet the requirements for establishment as a $\mathrm{PT}$ or a cooperative. If continued to use these provisions, CIC-ABS will not get permission from the Finance Minister as a Financing Company. It should be considered, as an alternative investment instrument, this CIC-ABS should be treated fairly by being recognized as a service institution in the financial sector. At least permits and approval by the Minister of Finance, though CIC-ABS is not established as a legal entity in the form of a PT or a cooperative.

\section{B. Impact of Applicable Tax Regulations on CIC ABS in Indonesia}

From the tax side, the uncertainty of capital market regulations regarding $\mathrm{CIC}-\mathrm{ABS}$ 's status will have implications for the imposition of taxes on this investment instrument. CIC, an agreement (legal form), is not a person and is not an entity, but in Article 2 of the Income Tax Law, it is recognized as an entity and subject to Corporate Income Tax. Even though the legal analysis, CIC-ABS, cannot categorize as a "business entity," but in terms of taxation regulations, it is classified as a Corporate Tax Subject, explained in the "other entity" category. Difference between provisions according to the law in general with the provisions under this tax can occur because the taxation regulations can specify otherwise for tax purposes without changing the provisions that refer to the law (including the Code of Civil Law). Because of the existence of the art of possibility, the government can assign CIC-ABS as a Corporate Tax Subject to explore potential tax revenue. However, the determination of CIC ABS as a tax subject must clearly and explicitly regulate taxation laws and regulations [11].

CIC-ABS is also designated as a Corporate Tax Subject because Indonesia is a country that adheres to a "nontransparent entity" in determining the status of liable to tax for the form of Partnership. A partnership is a business entity owned by two or more people who work together to achieve business goals. However, CIC-ABS characteristics do not meet the criteria as a partnership company in Indonesia and do not meet the "business entity" element in the definition of the Partnership. However, the tax takes a proxy that the CIC-ABS established by the Investment Manager and the Custodian Bank is in line with two elements of the Partnership, namely "owned by two or more people collectively" and "to achieve business goals." Another basis used to justify the taxation status of CIC $\mathrm{ABS}$ is that it equated with a capital association that is divided into shares, as the definition of a limited liability company in Article 4 paragraph (3) letter i of the Income Tax Law.

Following the conditions described above, taxation will be carried out at the entity level, so that the Partnership is treated as a taxable entity. The existence of a tax regulation that determines of CIC ABS as a tax subject deemed has fulfilled the element of certainty in tax law. Also, the background to such determination is considered to provide ease of administration for tax office and is expected to encourage the speed of fulfilling tax revenue target, concerning the CIC-ABS entity's determination as withholder on investors' income.

The phrase "based on general provisions" in Article 3 KEP$147 / 2003$ indicates that CIC-ABS does not accept any tax exemptions related to the Income Tax aspect. Therefore, the types of income tax that apply to CIC-ABS transactions are the same as for entities in general without any notable exceptions, including Corporate Income Tax and Withholding Income Tax.

One of the tax issues highlighted was the deduction of WHT Income Tax Article 23 of margin payments received by $\mathrm{CIC} \mathrm{ABS}$ on principal returns from the Originator. The margin 
received by CIC ABS is considered as interest. Based on Article 23 Paragraph (4) of the Income Tax Law, there is an exemption from withholding Income Tax Article 23, namely on income paid or payable to business entities for financial services that function as lenders and financing providers regulated by a Regulation of the Minister of Finance. However, considering that CIC-ABS does not meet a finance company's requirements, CIC-ABS cannot accept this exemption. It is one of the implications of the unclear form of business of CIC ABS in Indonesia. This condition has further consequences for CIC ABS.

CIC ABS's position in asset securitization only acts as a manager and collective custody, so that all income will be passed on to investors. Thus, when calculating Corporate Income Tax, generally, the position of the taxable income is 0 . The deduction of PPh 23 on the margin received by CIC ABS causes the overpayment position on the CIC ABS Corporate Income Tax Return. It has an impact on the inspection that will be carried out by the tax office when CIC ABS makes a tax refund request. The examination period can reach a maximum of 12 months from the time the application letter is received as regulated in Article 17B Paragraph (1) of Law Number 28 of 2007 concerning General Provisions and Tax Procedures. This condition will affect the liquidity of CIC ABS and become a troublesome tax issue for actors [12].

Another issue faced by CIC ABS over the taxation regulation of asset-backed securities is related to the potential for economic double-taxatioan. According to Lyon, economic double-taxation is a phenomenon of taxing the same income more than once [13]. In this case, this economic doubletaxation occurs on the margin income received by CIC-ABS. When $\mathrm{CIC}-\mathrm{ABS}$ receives the income, the Originator has deducted Article 23 Income Tax at $15 \%$ on the gross amount received. Then, when the CIC-ABS income continues the payment of the income to the holder of the CIC-ABS Fixed Cash Flow equalization unit, the income is again deducted by the tax in the form of Final Income Tax at a rate of $15 \%$ (PP $55 / 2019$ ).

The reduction in the tax rate on bond interest received by CIC ABS as regulated in Government Regulation Number 55 of 2019, is not quite right on target. No originator has yet sold financial assets in bonds as their underlying assets to CIC-ABS in Indonesia. The issuance of CIC ABS with bonds as the underlying asset will not be attractive. The bond sale does not require an asset securitization process because it is an effect from the start. Bonds also do not require CIC-ABS as an "issuer" like ABS issuance because bonds can be issued directly by issuers, both companies, and governments, as direct bond issuers, to investors without requiring SPV such as CIC as the intermediary. Thus, the special rates for CIC-ABS regulated in PP-55/2015 will also not have much effect on CIC-ABS.

\section{CONCLUSION}

Asset securitization is an alternative for infrastructure financing in Indonesia. However, to attract investors' interest, it is necessary to review the regulations and related taxation due to several developing issues. The first is associated with the business form of CIC-ABS. Second, related to the applicable tax regulations and their impact.

The study results explain that no regulation regulates the form of business of CIC ABS in Indonesia, whether financial institutions, financial services, banks, or the like. By law, KIK is an agreement contract that is a legal form, not a business entity. Based on the transactions, CIC-ABS equates with factoring because it has the same characteristics as factoring, which is one of the business activities of a financing company in Indonesia. The uncertainty of regulations regarding CICABS's status will have implications for the imposition of taxes on this investment instrument. CIC ABS does not get an exemption from withholding Income Tax Article 23 on margin income. It impacts the inspection that will be carried out by the tax office when CIC ABS makes a tax refund request. Restitution takes a maximum of 12 months to complete from the time the application is received until the state returns the overpaid taxes. Overpayments of taxes disrupt the liquidity of CIC ABS. Besides, the potential for economic double-taxation that occurs on margin income provided by the originator. This income is subject to tax at the CIC ABS level and at the investor level.

\section{REFERENCES}

[1] Directorate General of Financing and Risk Management, Ministry of Finance, "Sekuritisasi Aset: Alternatif Pembiayaan Infrastruktur dan Peluang Investasi dalam Pembangunan Infrastruktur", 2017, [Online]. Retrieved from: https://www.djppr.kemenkeu.go.id/uploads/files/Sosialisasi\%20SBN/Inv estor\%20Gathering\%202017_Sekuritisasi\%20Aset.pdf

[2] NERACA, "Danai Infrastruktur, Sekuritisasi Aset Bisa Jadi Strategi," December 2017, [Online]. Retrieved from https://idxchannel.okezone.com/read/2017/12/05/278/ 1825335/danaiinfrastruktur-sekuritisasi-aset-bisa-jadi-strategi

[3] Y. Bhattaarai and D. Baxi, "Tax Treatments of Securitization of Receivables," International Bureau of Fiscal Documentation Journal, no. Derivatives \& Finance Instruments, 2002.

[4] Amelia, Sekuritisasi Aset Sebagai Alternatif Strategi Pendanaan pada Bank XYZ. Depok: Faculty of Social and Political Science, University og Indonesia, 2011

[5] S. Suselo, R. Soekro and R. Nugraha, Working Paper Bank Indonesia: Sekuritisasi Aset Lembaga Pembiayaan dan Pengembangan Pasar Secondary Mortgage Facility dalam Rangka Pendalaman Pasar Keuangan Indonesia. Jakarta: Bank of Indonesia, 2013.

[6] J. Han, K. Park, and G. Pennacchi, "Corporate Taxes and Securitization," The Journal of Finance, vol. 70, no. 3, pp. 1287-1321, 2015 .

[7] Otoritas Jasa Keuangan Republik Indonesia, Pedoman Otoritas Jasa Keuangan Nomor 6/POJK.04/2017 tentang Pedoman Penerbitan dan Pelaporan Efek Beragun Aset Berbentuk Kontrak Investasi Kolektif, Jakarta: Otortitas Jasa Keuangan RI, 2017 
[8] F.A. Andi, Interviewee, Depth Interview. [Fiscal policy Agency]. 6 May 2020.

[9] W. Setiawati, Interviewee, Depth Interview. [Law Academic]. 13 June 2020 .

[10] The Republic of Indonesia, Law Number 36 of 2008 Concerning Income Tax, State Gazette of The Republic of Indonesia of 2008 Number 133 , 2008 .
[11] Gunadi, Interviewee, Depth Interview. [Tax Policy and Administration Expert]. 20 June 2020.

[12] C. Hadiputranto, Interviewee, Depth Interview. [CIC-ABS Representative]. 10 June 2020.

[13] S.M. Lyon, International Tax Glossary, Amsterdam: IBFD Publication BV, 1996. 